\title{
RE-EVALUATING HYDROCHEMICAL DATA FROM AQUIFERS OCCURRING IN THE RIO CLARO CITY REGION, SÃO PAULO STATE, BRAZIL
}

\author{
RAQUEL CURTOLO QUIRINO \& DANIEL MARCUS BONOTTO \\ Departamento de Petrologia e Metalogenia, Instituto de Geociências e \\ Ciências Exatas - UNESP, Rio Claro, Brazil
}

\begin{abstract}
Groundwater use increases every year in different sectors of the society, therefore, hydrochemical studies of aquifers and their relations with the anthropic environment are crucial. With an area of approximately $1,880 \mathrm{~km}^{2}$, comprising Rio Claro city and near districts, the study assembles a series of groundwater data from previous assessments and aims using available tools to reach a new approach regarding the data in the literature. The database comprised a total of 41 groundwater samples from regional wells exploiting the aquifer systems Rio Claro, Serra Geral, Guarani, and Tubarão, as well the Passa Dois aquiclude, all them situated in the Paraná basin geological context. Locally, the study area is associated with a sedimentary deposit of sandstones, shales, limestones and unconsolidated sediments. The data of the chemical analyses of major ions and main physical parameters of the water samples were re-evaluated through The Geochemist's Workbench 11.0.5 software and compared with three water potability standards: São Paulo State Environmental Agency, Brazil Health Ministry, and World Health Organization. Moreover, a series of hydrochemical diagrams and graphs (Piper, Schoeller, Stiff and Durov) were generated in order to classify the samples and evaluate their local behavior in comparison with the data of other aquifers in São Paulo State.
\end{abstract}

Keywords: aquifers, hydrochemical, water standards.

\section{INTRODUCTION}

This study was held at Rio Claro city and adjacent municipalities, São Paulo State, southwest Brazil (Fig. 1). The region occupies an area of $\sim 1,880 \mathrm{~km}^{2}$ and its population is circa 520 thousand inhabitants. The largest ceramic pole in Latin America is located in the area; moreover, agriculture, livestock, sugar-alcohol industries and other industrial activities represent the local economic base. According to CETESB [1], in 2016, about $80 \%$ of the municipalities used groundwater in their water-supply systems, including two cities (Itirapina e Ipeúna) focused in this study.

A detailed study of the groundwater composition and relationship with the biotic and anthropic environment is increasingly necessary due to its enhanced use coupled to the economic activities developed in the surrounding districts. In addition, detailing the behavior of the groundwater contributes to improve the water management system, providing resources to prevent crises like that affecting São Paulo State in 2014 and 2015. This research also contributes for identifying areas of potential groundwater pollution by comparison with different potability standards (Brazil Health Ministry, CETESB - São Paulo State Environmental Agency, and WHO - World Health Organization).

Previous investigators [2]-[4] realized hydrogeological and hydrochemical studies in the area. Annual reports about the groundwater quality in São Paulo State from DAEE (Water and Electricity Department) and CETESB were used in this study, as well the hydrochemical database reported by [4]. 


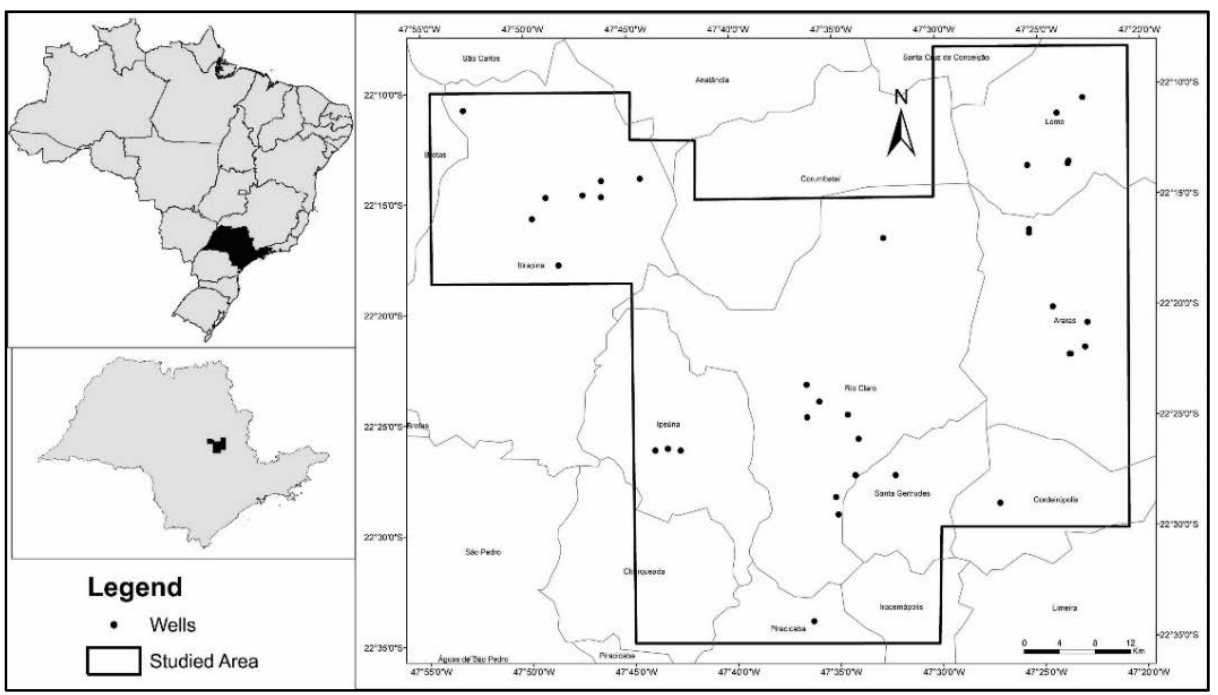

Figure 1: Location of studied wells in the selected area of this paper.

\section{GENERAL FEATURES OF THE STUDIED AREA}

The study area is inserted in the geological context of Paraná Sedimentary Basin, which covers about 1.1 million $\mathrm{km}^{2}$ in Brazil. Distinct aquifer systems (Rio Claro, Serra Geral, Guarani, Tubarão) and Passa Dois aquiclude occur there (Fig. 2).

Rio Claro aquifer (RCA) has restricted local occurrence, where unconsolidated sandstones from Rio Claro Formation mark its lithological framework. Its flow ranges between 5 and 25 $\mathrm{m}^{3} / \mathrm{h}[3]$ and the water is used for supplying small local communities.

Serra Geral Aquifer System (SGA) is a fractured aquifer occurring in the western part of São Paulo State. The groundwater is stored in fractures of basaltic lava flows setting from Serra Geral Formation. Its flow ranges between 7 and $100 \mathrm{~m}^{3} / \mathrm{h}$ (average $=23 \mathrm{~m}^{3} / \mathrm{h}$ ) [5].

Guarani Aquifer System (GAS) is considered one of the largest aquifers in the world (total area $=1.2$ million $\mathrm{km}^{2}$ ). It occupies $76 \%$ of the territory of São Paulo State and is confined in the majority of its occurrence [5]. The host rocks of this aquifer are well-selected sandstones with a high amount of interconnected pores from Pirambóia and Botucatu formations, which grant a high storage capacity. Reports indicate flows over $500 \mathrm{~m}^{3} / \mathrm{h}$, although the average flow from exploited wells is $360 \mathrm{~m}^{3} / \mathrm{h}[6]$.

The siltstones, mudstones, shales, diamictites and sandstones that compose the Itarare Group form the framework of the Tubarão Aquifer System (TAS). Its productivity is low, with an average flow of $10 \mathrm{~m}^{3} / \mathrm{h}$, being exploited in the outcropped portion [5].

Passa Dois aquiclude (PDA) is a hydrogeological unit separating GAS and TAS. The characteristics of the host rocks (shales, siltstones, mudstones and limestones) make difficult the vertical water movement. Thus, in a regional scale, Passa Dois Group is considered an aquiclude.

Two geomorphological compartments occur in the studied area: Peripheral Depression (altitudes between 500 e $650 \mathrm{~m}$ ), marked by broad, tabular and convex hills tops; Basaltic "cuestas" (up to $850 \mathrm{~m}$ high), characterized by hills occurring around the area [7]. Rio Claro city is located in the hydrographic basin of Corumbataí River, whose main tributaries are Passa Cinco River and Claro creek. 


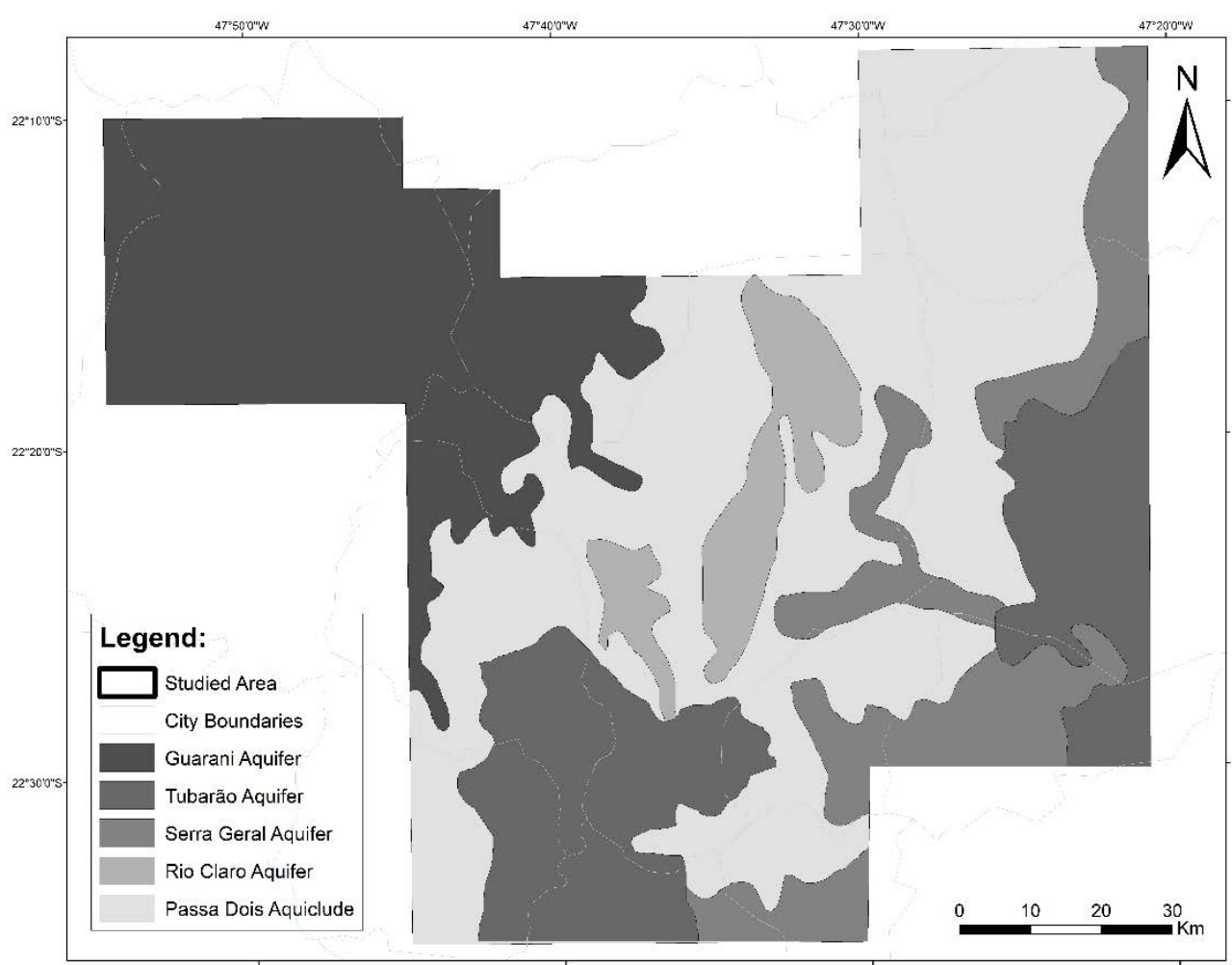

Figure 2: Hydrogeological map of the studied area. According to [8].

According to the Köppen-Geiger classification, the studied area present two climatic variations, i.e. tropical climate (dry winter season) and temperate (dry winter and hot summer). The annual average temperature is $22^{\circ} \mathrm{C}$, whereas the annual rainfall varies between 1,325 and $1,500 \mathrm{~mm}$. The vegetation covering the region is mostly characterized by semideciduous broadleaved forest with traces of savanna and trees formation.

\section{MATERIALS AND METHODS}

This study started from bibliographic review of researches developed at Rio Claro area, and the database reported by [4] was chosen due to its wide coverage area, including the occurrence of different aquifers and a large number of analyzed parameters. The database is composed of information about 62 wells with hydro chemical analysis performed in 41 .

The Geochemist's Workbench Student Edition 11.0.5 software was used to generate Piper and Schoeller diagrams for the data re-evaluation. The statistical analysis was held with Microsoft Excel 2013 in order to build box plot graphs for evaluating the dispersion of variables involved in the potability standards. The flowchart showed in Fig. 3 outlines the steps performed in this study.

Hydro chemical analysis characterized the groundwaters in terms of pre-established targeted parameters aimed for the objectives of this study. The selected major ions practically comprise the whole composition of the groundwater, allowing its classification. They are: calcium $\left(\mathrm{Ca}^{2+}\right)$, magnesium $\left(\mathrm{Mg}^{2+}\right)$, sodium $\left(\mathrm{Na}^{+}\right)$, potassium $\left(\mathrm{K}^{+}\right)$, bicarbonate $\left(\mathrm{HCO}_{3}{ }^{-}\right)$, 


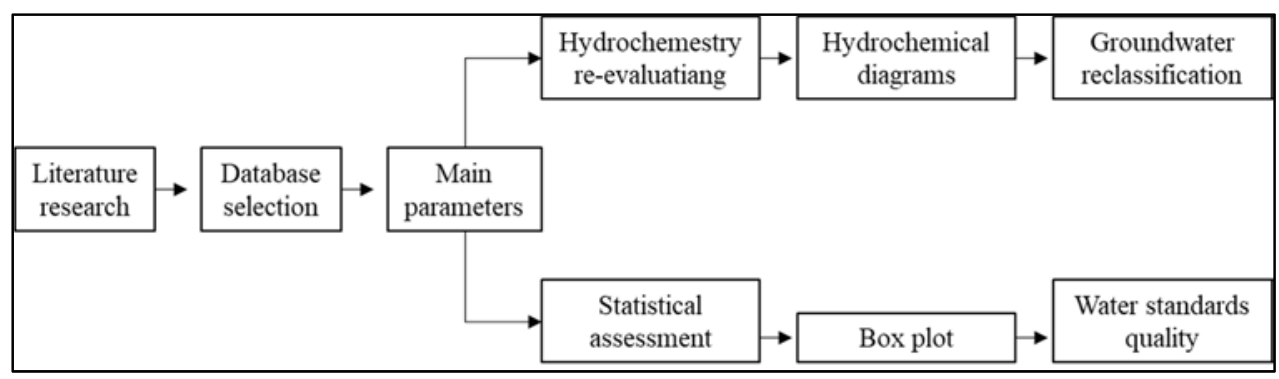

Figure 3: Flowchart of the steps involved in this study.

sulphate $\left(\mathrm{SO}_{4}{ }^{2-}\right)$ and chloride $\left(\mathrm{Cl}^{-}\right)$. Concentrations of nitrate $\left(\mathrm{NO}_{3}{ }^{-}\right)$and fluoride $\left(\mathrm{F}^{-}\right)$were also selected due to some high levels found in area. The $\mathrm{pH}$ and water temperature values were also used for checking the quality standards.

The groundwater sampling of the database was done between November 1998 and November 1999 [4]. Five litters of water was collected from the nearest exit well and waters were kept at $4^{\circ} \mathrm{C}$ until analysis. The use of filters and chlorination were interrupted for sampling.

In order to check the groundwater potability, three guidelines were used at global, national and state (local) levels. The WHO publication "Guidelines for Drinking-water Quality" was used at a global level [9]. In Brazil, at a national level, it was adopted the Ordinance No. 2914 from Health Ministry that regulates the water standards for human consumption. In São Paulo State, CETESB acts as the body regulating the water quality standards in the state (local level). The values proposed by CETESB are based in biennial reports about the groundwater quality in the state, differing in some parameters from those established by the Brazilian Health Ministry and WHO because specific characteristics from each aquifer are taken into account.

\section{RESULTS}

\subsection{Serra Geral Aquifer (SGA)}

The SGA samples show a pH range between 6.5 and 7.0 with average temperature of $25.7^{\circ} \mathrm{C}$. According to the Piper diagram (Fig. 4), most of the waters are of sodium chloride-sulfate type. The Schoeller diagram (Fig. 4) shows, in logarithmic scale, the following ions concentration variation: $\mathrm{Na}^{+}>\mathrm{K}^{+} \geq \mathrm{Mg}^{2+}$ and $\mathrm{Ca}^{2+}$ and $\mathrm{HCO}_{3}^{-}>\mathrm{Cl}^{-}>\mathrm{NO}_{3}>\mathrm{SO}_{4}{ }^{2-}>\mathrm{F}$. Previous researches classify these waters as calcium-magnesium bicarbonate and sodium bicarbonate type. Groundwater from basaltic aquifers are typically characterized as calcium bicarbonate as a consequence of the dissolution of pyroxene $\left(\mathrm{Ca}^{2+}\right)$ and plagioclase $\left(\mathrm{Na}^{+}\right.$and $\left.\mathrm{Mg}^{2+}\right)$.

\subsection{Guarani Aquifer System (GAS)}

The GAS samples present a $\mathrm{pH}$ range between 5.6 and 6.2, exhibiting acid characteristics. The average temperature is $25.2^{\circ} \mathrm{C}$. The Piper diagram (Fig. 5) classifies the water as sodium chloride-sulfate type. The Schoeller diagram (Fig. 5) clearly shows the sodium dominance in comparison to other cations and a higher content of chloride in relation to other anions. 


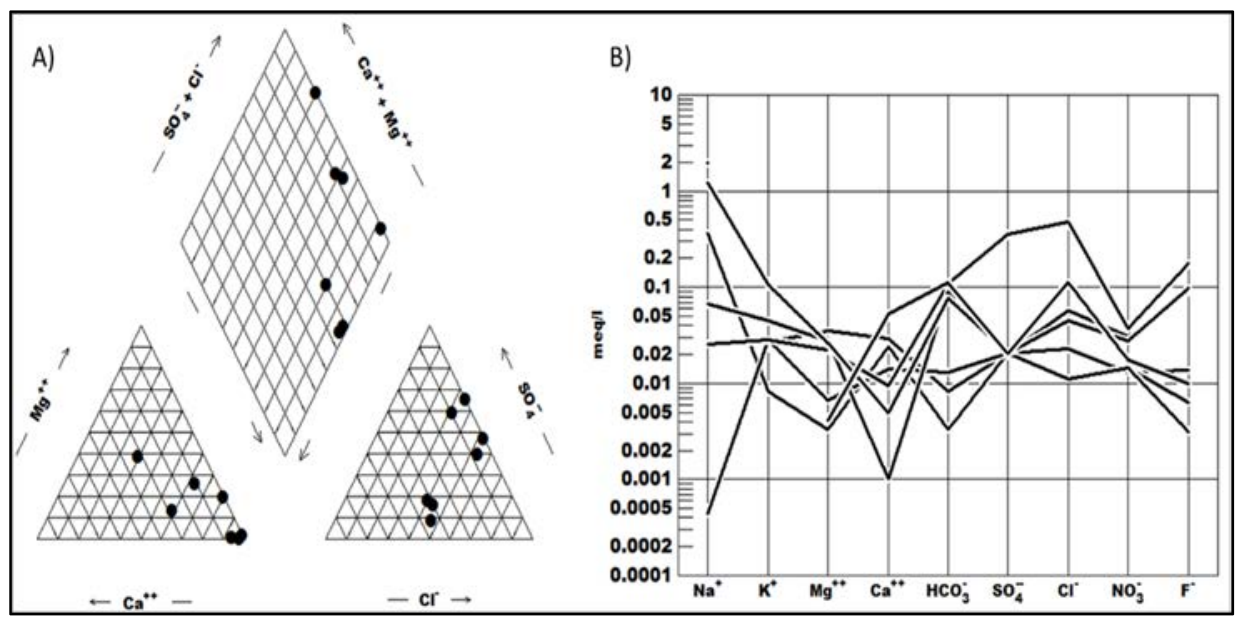

Figure 4: (a) Piper diagram; and (b) Schoeller diagram for SGA groundwaters, showing the relation of major ions.

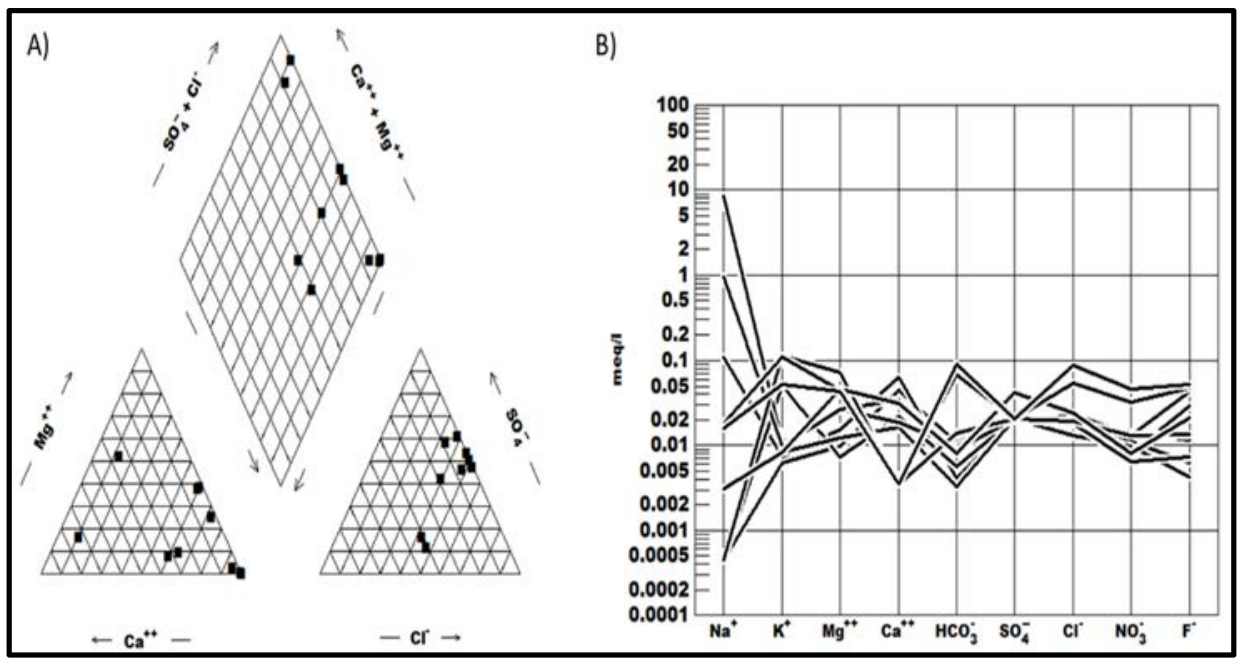

Figure 5: (a) Piper diagram; and (b) Schoeller diagram for GAS groundwaters.

According to CETESB [1], the GAS waters are mainly characterized as calcium bicarbonate and sodium bicarbonate type.

\subsection{Passa Dois Aquiclude (PDA)}

Only three samples were collected from PDA, since it is a restricted unit with low productivity. Two samples are of sodium chloride type, following the trend in the area, whereas the remaining sample is of chloride-sulfate magnesium type (Fig. 6). The relation of the main ions is: $\mathrm{Na}^{+}>\mathrm{K}^{+}>\mathrm{Mg}^{2+}>\mathrm{Ca}^{2+}$ and $\mathrm{Cl}^{-}>\mathrm{SO}^{2-}>\mathrm{NO}^{-} \geq \mathrm{HCO}^{-}$and $\mathrm{F}^{-}$. PDA is the 
most unknown unit due to its low productivity and lack of detailed hydrochemical characterization.

\subsection{Tubarão Aquifer System (TAS)}

The TAS samples present a $\mathrm{pH}$ range of 8.5 to 9.5 , showing alkaline conditions for these waters. The average water temperature is $26^{\circ} \mathrm{C}$. Most of the sampled waters are of sodium sulfate type (Fig. 7). The Schoeller diagram shows the following relation: $\mathrm{Na}^{+}>\mathrm{Mg}^{2+}>\mathrm{K}^{+}>\mathrm{Ca}^{2+}$ and $\mathrm{SO}_{4}^{2-}>\mathrm{F}^{-}>\mathrm{Cl}^{-}>\mathrm{HCO}_{3}{ }^{-}>\mathrm{NO}_{3}{ }^{-}$. According to previous studies [10], the TAS groundwater may present two hydrochemical facies: sodium bicarbonate type and calcium bicarbonate type.

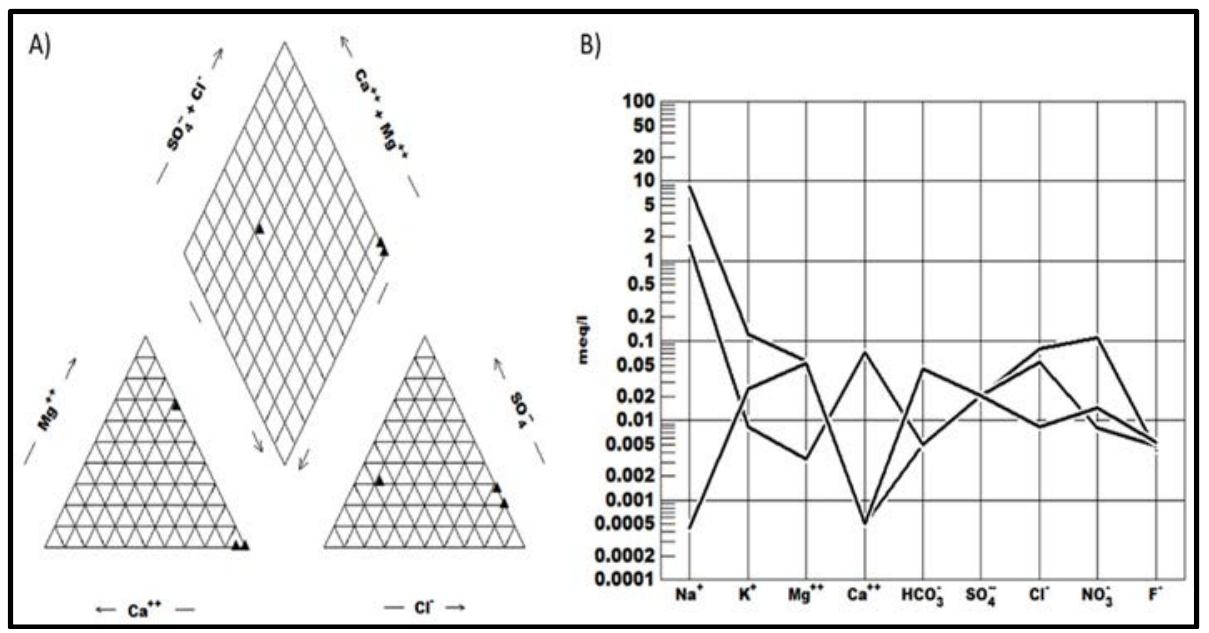

Figure 6: (a) Piper diagram; and (b) Schoeller diagram for PDA groundwaters.

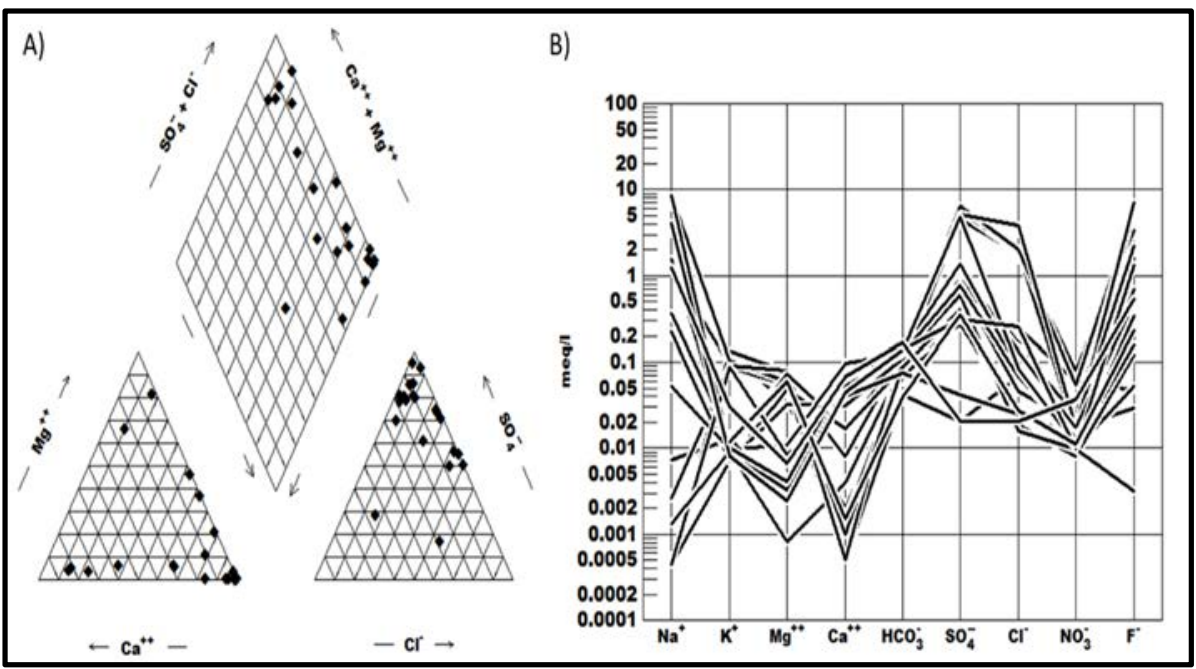

Figure 7: (a) Piper diagram; and (b) Schoeller diagram for TAS groundwaters. 

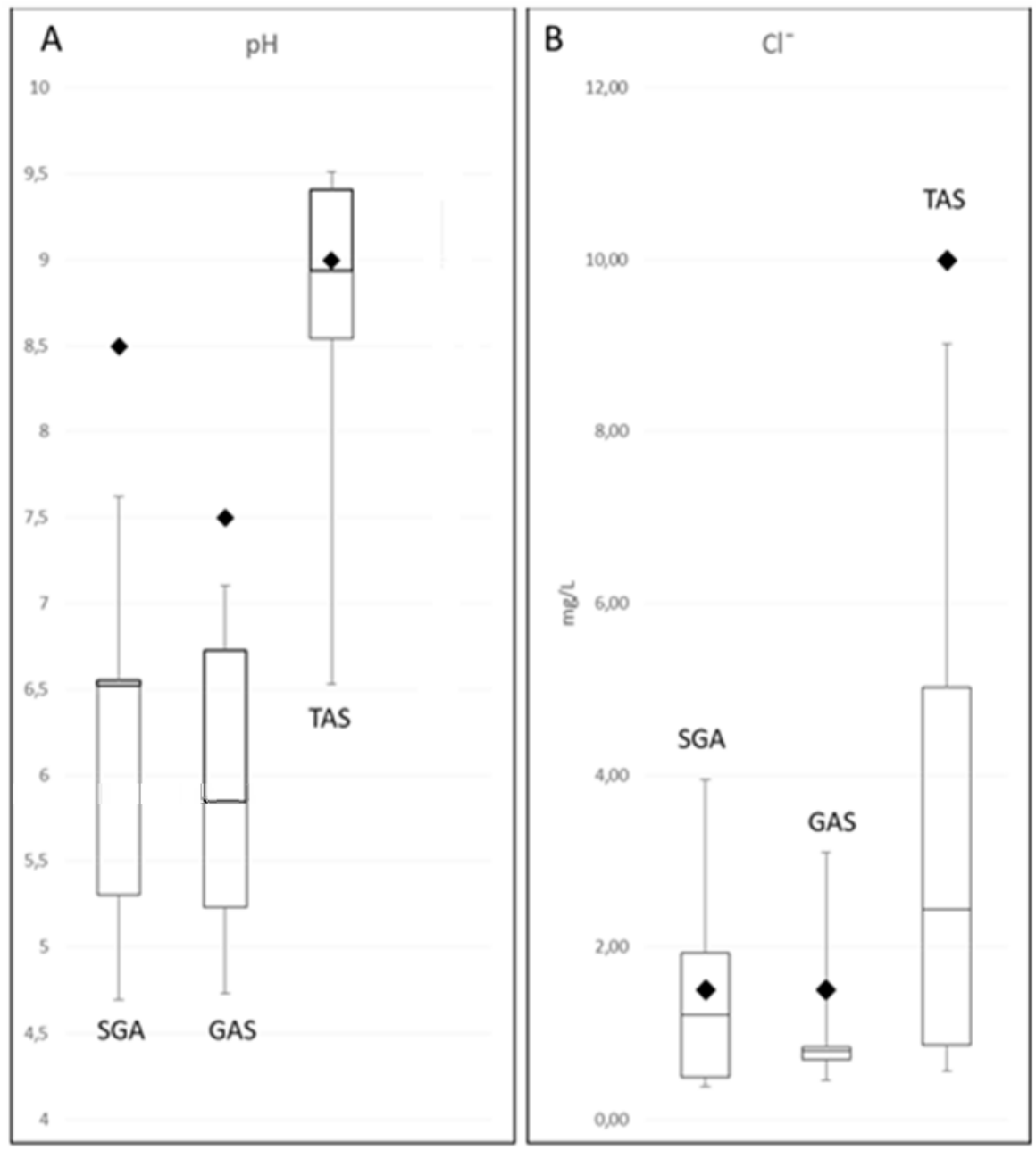

CETESB values.

Figure 8: Box plot graphs for (a) $\mathrm{pH}$ and (b) chloride showing the spatial distribution of values from studied aquifers compared to the reference values established by CETESB.

\section{DISCUSSION}

The values reported in the database were compared with the guideline reference values established by CETESB, Brazilian Health Ministry and WHO. Usually, the pH does not present a direct health impact on the consumers. However, it is one important parameter as exerts control on the reactions occurring in subsurface. The WHO [9] suggests that the $\mathrm{pH}$ values must range between 6.5 and 9.5. The box plot graph (Fig. 8) shows that part of all sampled waters are outside that range (the majority of the GAS samples are under 6.5). Almost $50 \%$ of the TAS waters exhibit $\mathrm{pH}$ higher than the guideline reference value established by CETESB. 
Sodium and its salts are commonly found in food and water, despite, in potable drinking water, its concentration usually does not exceed $20 \mathrm{mg} / \mathrm{L}$. According to WHO [9], values above $200 \mathrm{mg} / \mathrm{L}$ may influence the water taste and should not be used for human consumption. Sodium is the cation with the highest concentration in relation to others in the studied area. Six samples from GAS and TAS exhibit values of $200 \mathrm{mg} / \mathrm{L}$, which could restrict these waters for human consumption. WHO does not establish a limiting value for potassium as this ion rarely appears in concentrations that are of concern for human consumption. The selected database shows that some samples exhibit values above of the guideline reference established by CETESB (Table 1).

Sulfate occurs naturally in several minerals, whose dissolution in the aquifer host rocks may cause its introduction into groundwater [9]. The WHO does not suggest a limit value for this anion in drinking water, despite levels above $200 \mathrm{mg} / \mathrm{L}$ may result in laxative effects and give a characteristic flavour to the waters. A few TAS samples exhibit values above it (Table 1).

Despite chloride occurs naturally in groundwater due to water/rock-soil interactions, it may also originates from sewage, industrial effluents, and saline intrusions. The WHO [9] guideline reference value is $250 \mathrm{mg} / \mathrm{L}$, which was not reached by any sample in the database (Table 1). Four TAS samples present values between 60 and $140 \mathrm{mg} / \mathrm{L}$ (Table 1).

For nitrate concentration, WHO establishes a guideline reference value of $50 \mathrm{mg} / \mathrm{L}$, whereas the Brazilian Health Ministry suggests $10 \mathrm{mg} / \mathrm{L}$. The nitrate concentration in the database does not reach the WHO guideline value, however, it is sometimes above the value orientated by CETESB (Fig. 9). High nitrate concentrations could indicate the presence of contamination from garbage deposits, sewage, septic tanks, and cemeteries among others. In the study area it could reflect the unplanned urban expansion.

Fluoride is an ion that in low levels (up to $1.5 \mathrm{mg} / \mathrm{L}$, according to WHO) is beneficial for human health, although can cause dental fluorosis and bones deformation if consumed for long periods in waters containing higher levels. The TAS samples showed the highest levels, reaching values close to $140 \mathrm{mg} / \mathrm{L}$ (Table 1), possibly related to the presence of phyllosilicate clays and mica that exhibit fluorine in their structures.

\section{CONCLUSION}

This study enabled the use of different tools for the re-evaluation of the hydrochemical database from previous work. The hydrochemical diagrams are essential to understand the relations between the main water ions and the environment in which water percolates. The statistical analysis allowed the data examination in the sample space, allowing the identification of discrepant levels and the comparison with data available in the literature comprising the studied aquifers. Based on the analysis of the results we may conclude that the studied area, in general, present sodium chloride-sulfate waters. This may occur due several factors, being the majority related to water mixing of the sampled wells. Most of the analyzed wells were built without adequate casing, which can lead to water mixing. In addition, the aquifers in Rio Claro region are in unconfined areas, therefore, more subjected to pollution. The large aquifer systems Tubarão, Guarani and Serra Geral extend over wide areas in São Paulo State, are heterogeneous and may present different hydrochemical characteristics when analyzed locally. Thus, it may be concluded that most of the groundwaters selected in the database are in accordance with the quality standards and values orientated by WHO which guarantees the safety of their use for human consumption. However, an accentuated disparity was identified between the database values and those suggested by CETESB, which may be related to the heterogeneous nature and variable characteristics of the aquifer systems throughout São Paulo State. 
Table 1: Concentration of the major ions from database utilized in this study [4].

\begin{tabular}{|c|c|c|c|c|c|c|c|c|c|c|c|c|}
\hline \multirow{8}{*}{ SGA } & Antern & set & $\infty$ & $c \sigma^{t}$ & $\mathrm{Mr}$ & $\mathrm{Nr}$ & $\mathrm{K}$ : & $\mathrm{HCOS}^{2}$ & sot & at & $\mathrm{Nat}-$ & $F$ \\
\hline & $\omega t-\infty$ & 460 & 27,00 & 0.9 & 0,43 & 0.01 & 1,05 & 0,50 & 1.00 & 0.28 & Qss & 0.86 \\
\hline & $\begin{array}{l}\text { Nots } \\
\text { vios }\end{array}$ & 170 & 2600 & 0,00 & 0.01 & $\mathbf{3 , 4}$ & 0.32 & 0.20 & 100 & $a n$ & $a \infty$ & 0.12 \\
\hline & ovt & 530 & & 0,38 & 0.08 & 0.01 & 1.00 & 0,00 & 1.00 & $a n$ & $a \infty$ & 006 \\
\hline & $212-9$ & 652 & 2600 & 0.19 & 0.27 & 459 & 1,10 & 6.60 & 17.90 & 1691 & 290 & 3,32 \\
\hline & $2 t 2-55$ & 602 & 23,00 & 0,02 & 0.41 & 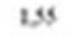 & 1,76 & sss & 100 & 203 & 1,00 & 1,73 \\
\hline & 212.86 & 648 & 25.50 & a.to & 0.32 & $2 \times 35$ & 4.77 & 1.65 & 1.00 & 1.44 & 1,70 & 187 \\
\hline & atros & 262 & 2600 & 192 & $20 x$ & 4604 & $\geq 7$. & 685 & 100 & 155 & 1,10 & 0.19 \\
\hline \multirow{10}{*}{ GAS } & mos & 4,73 & & 0.90 & 0.12 & 201 & 0.24 & 0.65 & 1.00 & ans & $a>0$ & 0.12 \\
\hline & 19206 & 47 & 2500 & 1.27 & 0.19 & 251 & 0.29 & 0.25 & 100 & an & as) & 0.22 \\
\hline & $213-28$ & 5.14 & & 0,44 & 0,000 & 0.91 & 200 & 0.35 & 1000 & as: & 0.50 & 0.82 \\
\hline & E19201 & 5.50 & & 0.33 & 0.15 & 30000 & 0.33 & 0.20 & 1.00 & Q.4s & 0.60 & 0.05 \\
\hline & E21702 & 500 & & 0.37 & 032 & 300.00 & 0.42 & 0.60 & 1.00 & 0.64 & $0,4)$ & 0.14 \\
\hline & Ear-03 & 600 & & 0.0 & $0 x 2$ & 22.25 & ats & 0.55 & 100 & an & 0.50 & 0.56 \\
\hline & MI-4! & 609 & 2000 & 0.97 & ess & 2.01 & 4,45 & oss & 100 & 0.60 & ass & 0,5 \\
\hline & Earot & 6,74 & & 0.63 & 0.86 & 2.07 & 0.33 & 0.50 & 2,00 & o.ss & 0.50 & 0,00 \\
\hline & $215-26$ & s.s. & 2500 & 0.08 & 0.44 & 0,11 & 4.25 & $4>0$ & 100 & 191 & 2,00 & 0.90 \\
\hline & 215.22 & 3.16 & 300 & 097 & 053 & o.4 & 204 & 58 & 100 & Mu. & 292 & 100 \\
\hline \multirow{3}{*}{ PDA } & $213-21$ & 120 & 24,00 & $<0.01$ & 0.00 & 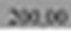 & 4,73 & 0.00 & 100 & 2.86 & 680 & 0,08 \\
\hline & $\begin{array}{c}\text { OUT } \\
21803\end{array}$ & & 26,0 & 1,45 & 0.04 & 36,13 & ass & $a \neq 0$ & 100 & 1,91 & 0,50 & 0,00 \\
\hline & cort & 2.17 & $2 t \times$ & ent & SAt & 201 & 03 & 200 & 100 & 0.32 & 02 & ate \\
\hline \multirow{14}{*}{ TAS } & 219.19 & 653 & 25,00 & 0.4 & 0.41 & 0.01 & 493 & ans & 1400 & 3.55 & $3 \times 0$ & 090 \\
\hline & $218-22$ & 7.16 & & 2.04 & 0.62 & 2835 & 360 & 255 & 100 & 2.43 & $1, n$ & 0.55 \\
\hline & $\begin{array}{l}218-08 \\
21908\end{array}$ & S.13 & & aes & 0.01 & & 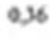 & 5,50 & 1200 & ess & ass & 1207 \\
\hline & OUT & 850 & 2000 & 1,27 & 0,04 & 0.17 & 0.6 & 5.30 & 51.60 & 2.45 & 0.60 & 100 \\
\hline & 19204 & & & & & & & & & & & \\
\hline & $\alpha T$ & 8.5 & & Q.93 & 0.65 & 20000 & 3,42 & 5,05 & 220,00 & 61,12 & (9) & 6412 \\
\hline & $218-13$ & 8.59 & 2260 & $\infty 001$ & 0.98 & 192.12 & 0.40 & 8.60 & 52.60 & 603 & 150 & 32.45 \\
\hline & 19204 & & & & & & & & & & & \\
\hline & OUT & 8.66 & & $\infty .01$ & 0.95 & 0.01 & 5,23 & 7.50 & 270,00 & 66,7 & 1.00 & 10934 \\
\hline & $\begin{array}{l}197-03 \\
\text { OUT }\end{array}$ & 87 & & 016 & 073 & 200 & 410 & 254 & 3 & $n 2 v$ & $3(4)$ & 1338 \\
\hline & 19) & 8.25 & & a.6? & 0.98 & 006 & 36 & s.3n & 1800 & 524 & 159 & 13071 \\
\hline & $218-08$ & & & & & & & & & & & \\
\hline & OUT & 9.93 & & 0.34 & 0.83 & 20000 & 0.40 & 754 & 220.00 & 134.15 & in & 137,00 \\
\hline & 219.31 & 9.97 & 3600 & 04 & 0.58 & 0,01 & 428 & 530 & 10.60 & 0.67 & ass & 200 \\
\hline \multirow[t]{11}{*}{$i$} & 219.10 & 933 & 2750 & Q.S & an & 920 & 0.28 & $a>0$ & 2500 & ast & $0 . \omega$ & Ges \\
\hline & $218-14$ & 9.35 & 0,00 & 133 & 0.13 & 1.21 & 038 & 7,25 & 37.60 & 164 & 1,20 & 4232 \\
\hline & $193-12$ & 9,00 & & ass & a to & 0,01 & $\mathbf{3 . 4}$ & 45 & 200 & 0.48 & $a n$ & 136? \\
\hline & 218.10 & 9,44 & $x, 00$ & 1.32 & 0.04 & 0.03 & 0.16 & 7,30 & 57,00 & 48 & 1,0 & 9.00 \\
\hline & 218.32 & 9,45 & 27,60 & L.44 & 0.03 & 8.44 & 051 & 805 & 6500 & 286 & Q.SA & 0.06 \\
\hline & $218-31$ & $9 ., 7$ & 25,00 & 1.64 & 0.04 & & ess & 255 & 37.00 & 2.41 & Q.85 & 2.65 \\
\hline & 21806 & & & & & & & & & & & \\
\hline & $\alpha T$ & 9.51 & 27,00 & 1,40 & 0.05 & 3613 & 0,40 & 805 & 230.00 & 3,01 & $a>0$ & 3.01 \\
\hline & OUT & & $x \in \infty$ & $0 \times 0$ & 093 & 9527 & 0.32 & 8135 & 1500 & 902 & 060 & 2523 \\
\hline & 218003 & & 2500 & 0.03 & 0.72 & & 2.46 & $20 n$ & $n=0$ & e.97 & $a \times 0$ & 4,43 \\
\hline & $257-64$ & & 2500 & I.us & oos & 2835 & 1.18 & 10.10 & 100 & o.tz & 2.30 & tous \\
\hline
\end{tabular}




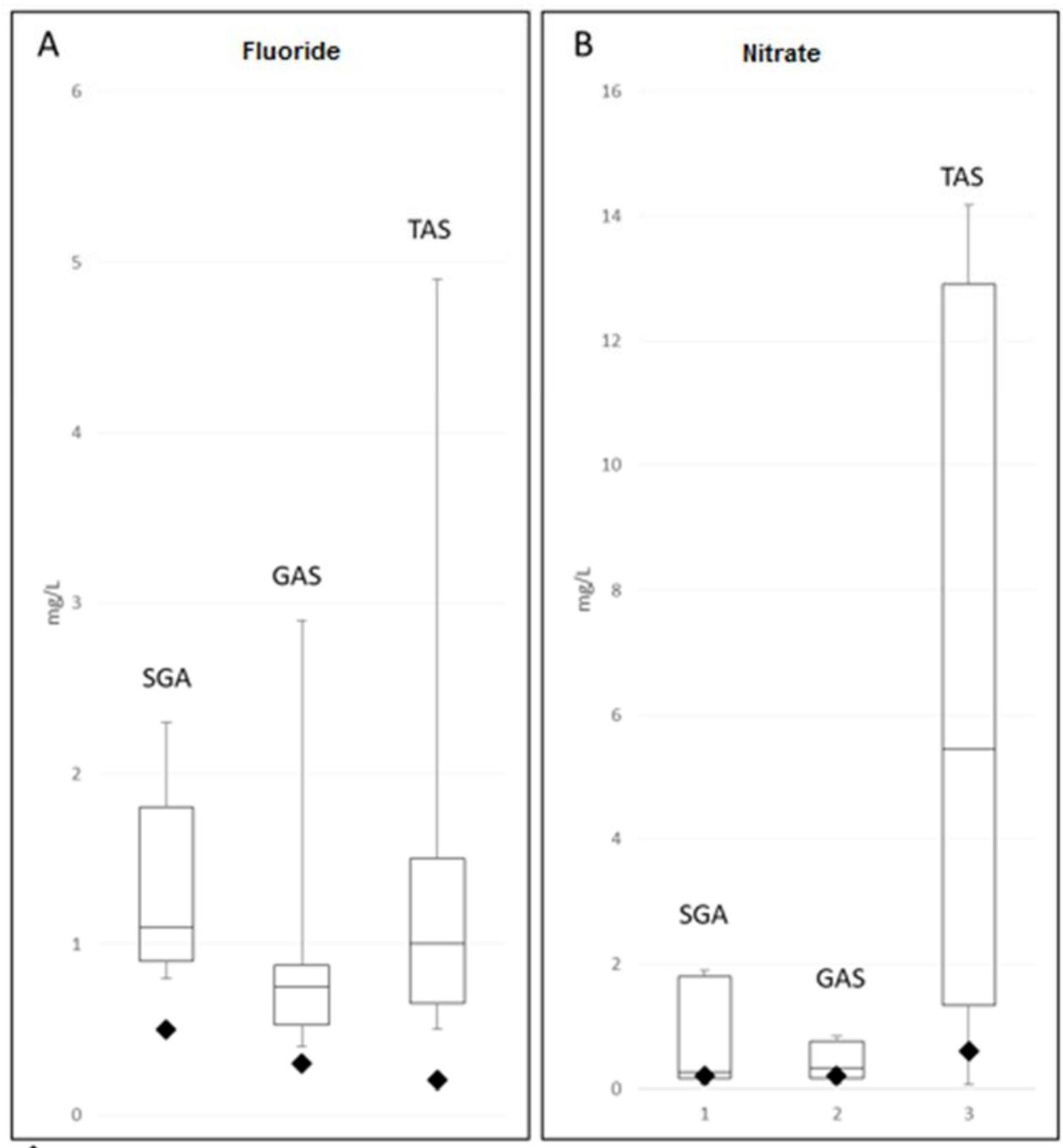

CETESB values.

Figure 9: Box plot graphs for (a) fluoride; and (b) nitrate showing the spatial distribution of values from studied aquifers compared to the reference values established by CETESB.

\section{REFERENCES}

[1] CETESB (Companhia Ambiental do Estado de São Paulo). Qualidade das águas subterrâneas do estado de São Paulo: 2013-2015, CETESB: São Paulo, p. 308, 2016.

[2] Bonotto, D.M. \& Mancini, L.H., Estudo Hidroquímico dos Aquíferos de Rio Claro (SP). Geochimica Brasiliensis, 6(2), pp 153-167, 1992.

[3] Oliva, A., Estudo hidrofaciológico do aquífero Rio Claro no município de Rio Claro SP. PhD thesis, Rio Claro (SP): São Paulo State University, p. 196, 2006. 
[4] Tonetto, E.M., Hidroquímica em aquíferos de Rio Claro (SP) e adjacências. PhD thesis, Rio Claro (SP): São Paulo State University, p. 108, 2001.

[5] Departamento de Águas e Energia Elétrica, Instituto Geológico, Instituto de Pesquisas Tecnológicas do Estado de São Paulo, Serviço Geológico do Brasil, Rocha G. Mapa de Águas Subterrâneas do Estado de São Paulo, São Paulo, 2005.

[6] Iritani, M.A. \& Ezaki, S., As Águas Subterrâneas do Estado de São Paulo, 2nd ed., Secretaria de Estado do Meio Ambiente: São Paulo, p. 104, 2009.

[7] Zaine, J.E. \& Penteado-Orellana, M.M., APA Piracicaba no município de Rio Claro, SP: proposta de mudança com base em critérios geomorfológicos e políticos. Presented at XXXVIII Congresso Brasileiro de Geologia, Balneário Camboriú, SC, Oct. 1994.

[8] Departamento de Águas Subterrâneas e Energia Elétrica, Instituto de Geociências e Ciências Exatas: Laboratório de Estudo de Bacias. Águas Subterrâneas no Estado de São Paulo: diretrizes de utilização e proteção. DAEE/LEBAC: São Paulo, p. 44, 2013.

[9] World Health Organization, Guidelines for Drinking-Water Quality, 4th ed. Gutenberg: Malta, p. 564, 2011.

[10] Diogo, A., Bertachini, A.C., Campos, H.C.N.S. \& Rosa, R.B.G.S., Estudo preliminar das características hidráulicas e hidroquímicas do Grupo Tubarão no estado de São Paulo. Presented at III Simpósio Regional de Geologia, Curitiba, PR, 1987. 